\title{
UPAYA PEMBERDAYAAN ANAK DI PANTI ASUHAN KUNCUP HARAPAN KOTA BANDUNG MELALUI PELATIHAN TEKNOLOGI INFORMASI
}

\author{
Maman Tarman \\ IKIP Siliwangi - Cimahi - Jawa Barat - Indonesia \\ mamantarman97@gmail.com
}

\begin{abstract}
Children who live or live in fostering orphanages, they can be said to be helpless children, because living in an all-round simplicity and even their shortcomings needs to be empowered in all respects in order to become empowered. including in the mastery of information technology. So every individual in the community must absolutely master information technology such as the use of computers and laptops and andoid-based cellphones, therefore, the Orphanage developed information technology training specifically in the operation and use of laptops, computers and Android-based cellphones. The theories used in this research are empowerment theory, training theory, and information technology theory. In this study, researchers used a qualitative descriptive method with data collection techniques through interviews and observations. This research was conducted at Kuncup Harapan Orphanage Jl. Garungang Kulon No 179/65 RT 06 RW 11 Sukabungah Sub-district, Sukajadi Sub-District of Bandung, the subject of the study were all children living in the orphanage. The results of this study are : (1) Knowing the mastery of information technology mastery of children living in Kuncup Harapan Orphanage, Bandung. (2) Provide an explanation to the Bandung City Hope Buddy Orphanage about the procedures for organizing information technology training; The conclusion of this study is that information technology training can improve the ability to master communication technology for children who live in the Kuncup Harapan Orphanage in Bandung.
\end{abstract}

Keywords: Child Empowerment, Information Technology Training.

\begin{abstract}
Abstrak
Anak-anak yang tinggal atau hidup dalam pembinaan panti asuhan, mereka bisa dikatakan anak-anak yang tidak berdaya, karena hidup dalam serba kesederhanaan bahkan kekurangan mereka perlu diberdayakan dalam semua hal agar menjadi berdaya. termasuk dalam penguasaan teknologi informasi. Setiap individu masyarakat mutlak harus menguasai teknologi informasi seperti penggunaan komputer, laptop dan HP berbasis andoroid, oleh karena itu, di Panti Asuhan dikembangkan pelatihan teknologi informasi khsusunya dalam pengoperasian dan penggunaan komputer/laptop dan HP berbasis android. Adapun teori yang digunakan dalam penelitian ini yaitu teori pemberdayaan, teori pelatihan, dan teori tekonologi informasi, Dalam penelitian ini peneliti menggunakan metode deskriptif kualitatif dengan teknik pengumpulan data melalui wawancara dan observasi. Penelitian ini dilakukan di Panti Asuhan Kuncup Harapan Jl. Garungang Kulon No 179/65 RT 06 RW 11 Kelurahan Sukabungah Kecamatan Sukajadi Kota Bandung yang menjadi subjek penelitian adalah seluruh anak yang tinggal dipanti asuhan. Hasil dari penelitian ini yaitu : (1) Mengetahui kemapuan penguasaan teknologi informasi anak-anak yang tinggal di Panti Asuhan Kuncup Harapan Kota Bandung,. (2) Memberikan penjelasan kepada pihak Panti Asuhan Kuncup Harapan Kota Bandung tentang tata cara penyelenggaraan pelatihan teknologi informasi, (3) Membantu pihak Panti Asuhan Kuncup Harapan Kota Bandung dalam menjalin kemitraan dengan lembaga atau organisasi yang bersedia bekerja sama dalam penyelenggaraan pelatihan teknologi informasi. Kesimpulan dari penelitian ini adalah pelatihan teknologi informasi mampu meningkatkan kemampuan penguasaan teknologi komunikasi bagi anak-anak yang tinggal di Panti Asuhan Kuncup Harapan Kota Bandung.
\end{abstract}

Kata Kunci : Pemberdayaan Anak, Pelatihan Teknologi Informasi. 
How to Cite: Tarman, M. (2020). Upaya Pemberdayaan Anak Di Panti Asuhan Kuncup Harapan Kota Bandung Melalui Pelatihan Teknologi Informasi. Comm-Edu (Community Education Journal), 3 (2), 122-128.

\section{PENDAHULUAN.}

Kementrian Sosial Republik Indonesia menjelaskan bahwa : Panti asuhan adalah suatu lembaga usaha kesejahteraan sosial yang mempunyai tanggung jawab untuk memberikan pelayanan kesejahteraan sosial kepada anak telantar dengan melaksanakan penyantunan dan pengentasan anak telantar, memberikan pelayanan pengganti fisik, mental, dan sosial pada anak asuh, sehingga memperoleh kesempatan yang luas, tepat dan memadai bagi perkembangan kepribadiannya sesuai dengan yang diharapkan sebagai bagian dari generasi penerus cita-cita bangsa dan sebagai insan yang akan turut serta aktif di dalam bidang pembangunan nasional.

Berdasarkan pemaparan diatas yang intinya anak-anak yang tinggal di Panti Asuhan merupakan bagian dari generasi penerus cita-cita bangsa dan sebagai insan yang akan turut serta aktif di dalam bidang pembangunan nasional, perlu diberdayakan akan mereka menjadi berdaya. Selaras dengan pendapat (Anwas, 2014) yang menjelaskan bahwa pemberdayaan adalah menyiapkan kepada masyarakat berupa sumber daya, kesempatan, pengetahuan dan keahhlian untuk meningkatkan kapasitas diri masyarakat di dalam menentukan masa depan mereka, serta berpartisipasi dan mempengaruhi kehidupan dalam komunitas masyarakat itu sendiri.

Menurut peneliti upaya pembedayaan anak dipanti asuhan yang sesuai dan menjawab kebutuhan saat ini adalah melalui pelatihan teknologi informasi, sebab Indonesia ke depan akan memasuki dalam era Revolusi industri 4.0, hal ini diutarakan oleh (Prayitno, 2018) bahwa Perpres No. 95 Tahun 2018 tentang Sistem Pemerintahan Berbasis Elektronik, serta Peraturan Pemerintah No. 24 Tahun 2018 tentang Pelayanan Perijinan Berusaha secara Elektronik. Ini sejumlah langkah yang dilakukan oleh pemerintah dalam menghadapi era Industri 4.0, dimana diera revolusi digital segala pelayanan usaha dan jasa yang diselenggarakan oleh pemberintah dan pihak swasta akan serba online dan berbasis internet yang hanya dibisa diakses melalui komputer/laptop dan HP berbasis android. Sehingga masyarakat dituntut untuk menguasai teknologi informasi dalam menghadapi era revolusi digital agar tidak tertinggal.

Anak-anak yang tinggal di Panti Asuhan yang merupakan bagian dari masyarakat, harus disiapkan perihal kemampuan teknoginya guna menghadapi era revolusi digital agar mereka tidak tertinggal. Dalam hal ini yang berkewajiban mempersiapkan mereka adalah pihak Panti Asuhan sebagai tempat mereka bernaung dan berlindung, sehingga ke depan pihak Panti Asuhan harus melaksanakan program pemberdayaan anak melalui pelatihan teknologi informasi sebagai upaya membekali anak-anak yang tinggal di Panti Asuhan, dengan kemampuan teknolgi informasi untuk menyongsong dan menghadapi era revolusi digital agar mereka tidak tertinggal.

Tujuan dari penelitian ini adalah (1) Mengetahui tingkat kemampuan penguasaan teknolgi informasi untuk anak-anak yang tinggal di Panti Asuhan Kuncup Harapan Kota Bandung, khususnya dalam pengusaan penggunaan komputer, laptop dan HP berbasis android yang sudah dapat dipastikan kurang menguasai, dan selanjutnya harus diberikan pelatihan untuk memperkuat penguasan IT mereka guna menghadapi era revolusi digital yang dicanangkan pemerintah saat ini (2) Memberikan masukan dan saran kepada pihak-pihak yang terkait khususnya pihak Panti Asuhan, agar ke depan harus melaksanakan program pemberdayaan 
124 Tarman, Upaya Pemberdayaan Anak Di Panti Asuhan Kuncup Harapan Kota Bandung Melalui Pelatihan Teknologi Informasi

anak di panti asuhan melalui pelatihan teknologi informasi yang terencana dan berkelanjutan guna mempersiapkan mereka menghadapi era rovolusi digital, agar anak-anak yang tinggal di panti asuhan melek teknologi tidak gaptek dan siap menyongsong era revolusi digital yang dicanangkan oleh pemerintah.

Adapun rumusan masalah peneliatan yaitu Bagaimana Upaya Pemberdayaan Anak di Panti Asuhan Kuncup Harapan Kota Bandung melalui Pelatihan Teknologi Informasi. yang dilatarbelakangi identifikasi masalah sebagai berikut :

1. Pemerintah akan menerapkan Era Revolusi Digital dimana setiap masyarakat harus menguasai teknologi dan informasi termasuk di dalamnya anak-anak yang ada di panti Asuhan, mereka harus disiapkan untuk menghadapi era revolusi digital yang dicanangkan pemerintah.

2. Anak-anak yang tinggal dipanti asuhan secara individu bisa dikatakan anak-anak yang tidak mampu baik secara ekonomi maupun financial, jadi harus ada pihak yang menggagas, memfasilitasi dan mewujudkan pelatihan teknologi informasi untuk mempersiapkan diri mereka utuk menghadapi era revolusi digital yang akan dicanangkan pemerintah.

3. Harus ada keperdulian melalui penelitian dan pengamatan untuk mengetahui tingkat dan perkembangan kemampuan IT untuk anak-anak yang ada di panti asuhan, dalam rangka mempersiapakan mereka menghadapai era revolusi digital yang dicanangkan pemerintah.

4. Apabila berdasarkan hasil penelitian dan pengamatan yang dilaksanakan ternyata anakanak yang tinggal di panti asuhan rata-rata penguasaan IT nya kurang, maka pihak panti asuhan harus melaksanakan upaya pemberdayaan anak di panti asuhan melalui pelatihan teknologi informasi yang akan memperkuat anak dalam penguasaan IT, untuk mempersiapkan mereka guna menghadapi era revolusi digital yang akan dicanangkan pemerintah.

\section{LANDASAN TEORI.}

Pemberdayaan.

Pemberdayaan salah satu cara memberikan solusi terhadap masalah yang di dapat atau di rasakan oleh masyarakat, sehingga masyarakat mampu memecahkan maslah secara mandiri. Istilah pemberdayaan semakin populer dalam konteks pembangunan dan pengentasan kemiskinan. Konsep pemberdayaan ini berkembang dari realitas individu atau masyarakat yang tidak berdaya atau pihak yang lemah. Keidak berdayaan atau memiliki kelemahan dalam aspek: penegetahuan, sikap, keterampilan, modal usaha, netwoorking, semangat, kerja keras, ketekunan, dan aspek lainnya. Kelemahan dalam berbagai aspek tadi mengakibatkan ketergantungan, ketidak berdayaan, dan kemiskinan. Pemberdayaan yaitu memberikan kekuatan kepada yang lemah. Istilah kekuasaan identik dengan kemampuan individu untuk membuat dirinya atau pihak lain melakukan apa yang diinginkannya. Kemampuan tersebut baik untuk mengatur dirinya, mengatur orang lain sebagai individu atau kelompok/organisasi, terlepas dari kebutuhan, potensi, atau keinginan orang lain. Dengan kata lain kekuasaan menjadikan orang lain sebagai objek dari pengaruh atau keinginan dirinya.

Menurut (Anwas, 2014) Pengertian pemberdayaan (empowerment) tersebut menekankan pada aspek pendelegasian kekuasaan, memberi wewenang, atau pengalihan kekuasaan kepada individu atau masyarakat sehingga mampu mengatur diri dari lingkungannya sesuai dengan keinginan, potensi dan kemampuan yang dimilikinya. Pemberdayaan tidak hanya memberikan kekuatan kepada yang lemah saja, dalam pemberdayaan mempunyai makna proses 
pembelajaran dalam meningkatkan kualitas individu, kelompok, atau masyarakat sehingga mampu berdaya, memiliki daya saing, serta mampu hidup mandiri. Kesimpulannya bahwa pemberdayaan masyarakat adalah memeberikan kekuatan kepada yang lemah atau kepada yang tidak berdaya agar menjadi berdaya, baik itu individu atau masyarakat agar mereka mampu menentukan masa depannya dan mampu bersaing, menambah pengetahuan, keterampilan dan bahkan bisa mengaplikasikan apa yang mereka pelajari, mereka bisa menemukan masalah yang mereka hadapi dan bisa memecahkan masalah tersebut.

\section{Pelatihan}

Noe \& Wright (2003) mengemukakan, "Training is a planned effort to facilitate the learning of job-related knowledge, skills, and behavior by employee". Hal ini berarti bahwa pelatihan merupakan suatu usaha yang terencana untuk memfasilitasi pembelajaran tentang pekerjaan yang berkaitan dengan pengetahuan, keahlian dan perilaku oleh para pegawai.

\section{Teknologi Informasi Pendidikan}

Menurut (Prasojo \& Riyanto, 2014) Teknologi Informasi Pendidikan : Adalah ilmu pengetahun dalam bidang informasi yang berbasis komputer yang digunakan dalam kualitas pendidikan.

\section{METODE PENELITAN.}

Pendekatan yang digunakan dalam penelitian ini adalah pendekatan kualitatif, yaitu suatu proses penelitian dan pemahaman yang berdasarkan pada metodologi yang meyelidiki suatu fenomena sosial dan masalah manusia. Menurut teori (Moleong, 2012: 4) dalam jurnal (Bogdan \& Taylor, 1993) "penelitian kualitatif adalah prosedur penelitian yang menghasilkan data deskriptif berupa kata-kata tertulis atau lisan dari orang-orang dan perilaku yang dapat diamati. Instrumen yang digunakan dalam penelitian ini adalah pedoman observasi, wawancara maupun sebagai angket.

Dalam penelitian yang dilaksanakan populasinya adalah seluruh anak-anak yang tinggal di Panti Aasuhan Koncup Harapan Kota Bandung yang berjumlah 14 orang, dimana mereka semua dijadikan sebagai subjek penelitian. Untuk penentuan sampling dalam penelitian yang dilaksanakan yaitu menggunakan tehknik non probability sampling, yang lebih mengarah ke penentuan jenis sampling jenuh, dimana menurut (Sugiono, 2017). Sampling jenuh adalah teknik penentuan sample bila semua anggota populasi digunakan sebagai sampel. Hal ini sering dilakukan bila jumlah populasi relatif kecil, kurang dari 30 orang, atau penelitian yang ingin membuat generalisasi dengan kesalahan yang sangat kecil. Istilah lain sampel jenuh adalah sensus, dimana semua anggota populasi dijadikan sampel. Berdasarkan hal tersebut diatas untuk sampling dalam penelitian yang dilaksanakan adalah seluruh anak-anak yang tinggal di Panti Asuhan Kuncup Harapan Kota Bandung sejumlah 14 orang dimana mereka semua dijadikan sebagai subjek penelitian. Lokasi penelitian bertempat di Panti Asuhan Kuncup Harapan Jl. Garungang Kulon No 179/ 65 RT 06 RW 11 Kelurahan Sukabungah Kecamatan Sukajadi Kota Bandung.

\section{HASIL DAN PEMBAHASAN.}

\section{Hasil.}

Anak-anak yang tinggal di Panti Asuhan bisa dikatakan adalah anak-anak yang tidak berdaya, mereka harus diberdayakan agar menjadi berdaya, salah satu program pembedayaan yang dibutuhkan oleh anak-anak yang tinggal di Panti Asuhan saat ini adalah program pemberdayaan melalui pelatihan teknologi informasi, sebab hal ini selaras dengan rencana 
126 Tarman, Upaya Pemberdayaan Anak Di Panti Asuhan Kuncup Harapan Kota Bandung Melalui Pelatihan Teknologi Informasi

pemerintah yang ke depan akan menerapkan era revolusi digital, dimana diera ini segala pelayanan usaha dan jasa yang diselenggarakan oleh pihak pemerintah maupun swasta akan menggunakan sistem digital yang berbasis internet dan online, yang menuntut semua masyarakat harus bisa menggunakan teknologi seperti penggunaan komputer/laptop dan HP berbasis android.

Berdasarkan hal diatas sangatlah tepat apabila anak-anak yang tinggal di Panti Asuhan saat ini diberdayakan melalui pelatihan teknologi informasi, untuk membekali mereka dalam menghadapi era revolusi digital yang akan dicanangkan dan diterapkan oleh pemerintah, sehingga anak-anak yang tinggal di Panti Asuhan bisa memanfaatkan dan menggunakan teknologi khususnya dalam penggunaan komputer dan HP berbasis android, sehingga mereka siap dalam menghadapi era revolusi digital yang akan dicanangkan dan diterapkan oleh pemerintah.

Selaras dengan hal tersebut peneliti mengadakan penelitian di Panti Asuhan Kuncup Harapan Jl. Garungang Kulon No 179/65 RT 06 RW 11 Kelurahan Sukabungah Kecamatan Sukajadi Kota Bandung. Dimana dalam penelitian tersebut anak-anak yang tinggal di Panti Asuhan dan lembaga menjadi subjek penelitian, adapun hasil penelitan :

a. Mengetahui kemapuan penguasaan teknologi informasi anak-anak yang tinggal di Panti Asuhan Kuncup Harapan Kota Bandung, sebagai dasar penguatan untuk mereka diberikan pelatihan teknologi informasi guna menghadapi era revolusi digital agar mereka tidak tertinggal.

b. Memberikan penjelasan kepada pihak Panti Asuhan Kuncup Harapan Kota Bandung tentang tata cara penyelenggaraan pelatihan teknologi informasi, agar ke depan pihak panti asuhan tidak kesulitan dalam menyelenggarakan pelatihan teknologi informasi, guna mempersiapkan anak-anak binaannya dalam mengahadapi era revolusi digital agar mereka tidak tertinggal.

c. Membantu pihak Panti Asuhan Kuncup Harapan Kota Bandung dalam menjalin kemitraan dengan lembaga atau organisasi yang bersedia bekerja sama dalam penyelenggaraan pelatihan teknologi informasi untuk anak-anak yang tinggal di pantinya, untuk memperkuat kegiatan pelatihan yang dilaksanakan.

\section{Pembahasan.}

Anak-anak yang tinggal di panti asuhan Kuncup Harapan Kota Bandung harus diberdayakan, agar mereka menjadi berdaya. Salah satu bentuk pemberdayaan yang harus dilaksanakan saat ini untuk mereka yaitu berupa pelatihan teknologi informasi, untuk mempersiapkan mereka mengahadapai era revolusi digital agar mereka tidak tertinggal, dimana diera revolusi digital yang akan diterapkan oleh pemerintah ke depan, menuntut setiap masyarakat harus menguasai teknologi informasi salah satunya penguasaan tentang pengoperasian komputer/laptop dan HP berbasis android. Karena diera revolusi digital ini, pelayanan usaha dan jasa yang diselenggarakan oleh pemerintah maupun pihak swasta akan berbasis online dan menggunakan internet dimana hal ini hanya bisa diakses melalui komputer/laktop dan HP berbasis android. Jadi mulai sekarang anak-anak sebagai generasi yang disiapkan untuk menyongsong dan menjalankan era reovolusi digital, harus dibekali dengan pengetahuan dan keterampilan tentang teknologi informasi, tidak terkecuali dengan anak-anak yang tinggal di Panti Asuhan mereka juga harus dibekali dengan pengetahuan dan keterampilan tentang teknologi informasi oleh pihak Panti Asuhan sebagai tempat mereka bernaung dan belindung agar mereka siap menghadapi era revolusi digital agar mereka tidak tertinggal, dengan suatu usaha melalui 
pelatihan teknologi informasi yang terprogram dan terencana. Dimana Pihak Panti Asuhan Kuncup Harapan Kota Bandung dalam melaksanakan kegiatan pelatihannya harus memperhatikan ketentuan-ketentuan, menurut (Rosenberg, 2001) dalam era perkembangan teknologi informasi dan komunikasi, sistem pelatihan perlu dirubah yaitu : (1) Menekankan bukan pada proses tetapi pada otuput pelatihan yang memberikan efek positif, (2) belajar dapat dilakukan dimana saja, kapan saja dengan kebutuhan dan kecepatan belajar yang fleksibel, (3) Dari kertas ke online, (4) Dari fasilitas fisik ke fasilitas jaringan dan (5) Materi pelatihan akan berganti cepat sesuai dengan kebutuhan sasaran yang nyata dalam kehidupannya.

Berdasarkan hasil penelitian disampaikan : (1) Bahwa anak-anak yang tinggal di Panti Asuhan Kuncup Harapan Kota Bandung, dalam penguasaan teknologi informasi khsusnya penguasaan pengoperasian komputer dan laptop masih sangat terbatas, walaupun untuk pengoperasian HP berbasis android rata-rata mereka bisa, tetapi hanya untuk sebatas untuk keperluan pribadi. Seperti penggunaan what app dan instragram, yang kedepannya harus diarahkan dan dilatihkan ke penggunaan HP untuk kepentingan mengakses suatu layanan dan jasa yang berbasis online dan digital, hal ini selaras dengan pernyataan (Setiawan, 2017) "Kebijakan Teknologi Informasi dan Komunikasi Untuk Mendorong Pembentukan Model Bisnis Masa Depan”. (2) Perlu disarankan kepada Pihak Panti Asuhan Kuncup Kota Bandung, agar kedepan mengadakan pelatihan teknologi informasi kepada anak-anak yang tinggal di pantinya, guna mempersiapkan mereka menghadapi era revolusi digital yang akan diterapkan oleh pemerintah. Hal ini diungkapkan oleh (Husaini, 2014) sesuai UUD 1945 yang mengamanatkan mengenai pentingnya pendidikan bagi seluruh warga negara seperti tertuang di dalam Pasal $28 \mathrm{~B}$ Ayat (1) bahwa setiap orang berhak mengembangkan diri melalui pemenuhan kebutuhan dasarnya, berhak mendapatkan pendidikan dan mendapatkan manfaat dari ilmu pengetahuan dan teknologi, seni dan budaya demi meningkatkan kualitas hidupnya demi kesejahteraan umat manusia, dan (3) Disarankan kepada pihak Panti Asuhan Kuncup Hararan Kota Bandung, agar menjalin kemitraan dengan lembaga/organisasi pendidikan dan kemasyarakatan dalam melaksanakan pelatihan teknologi informasi kepada anak-anak yang tinggal di pantinya, utuk memperkuat kegiatan pelatihan yang dilaksanakan. Hal ini didukung oleh pendapat Wong, Fearon dan Philip (2007) dalam jurnal (Hayati \& Suparjan, 2017) yang menyatakan kemitraan adalah strategi yang diciptakan untuk melibatkan pihak lain dalam bentuk partisipasi yang berdasarkan prinsip mutual benefit gains.

\section{KESIMPULAN.}

Tidak bisa dipungkiri bahhwa era revolusi digital akan segera diterapkan oleh pemerintah, dimana seluruh lapisan masyarakat mau tidak mau dan suka tidak suka harus mempersiapkan diri untuk menyongsong era ini. Anak-anak sebagai generasi yang disiapkan untuk menyongsong dan menghadapi era revolusi digtital, mulai dari sekarang harus dibekali pengetahuan dan keterampilannya tentang penguasaan teknologi informasi. Tidak terkecuali anak-anak yang tinggal di Panti Asuhan, mereka juga harus disiapkan untuk menyongsong dan menghadapi era revolusi digital agar mereka atidak tertinggal, dengan cara dibekali pengetahuan dan keterampilan tentang penguasaan teknologi informasi. Panti Asuhan sebagai tempat mereka bernaung dan berlindung berkewajiban melaksanakan usaha pemberdayaan anak melalui pelatihan teknologi informasi, untuk mempersiapkan anak-anak yang tinggal di pantinya menghadapai era revolusi digital agar mereka tidak tertinggal. Mungkin program pelatihan teknologi informasi pada anak-anak yang tinggal di Panti Asuhan, bukan salah satu yang terbaik tetapi menjadi salah satu cara yang tepat saat ini dalam memecahkan masalah sosial ini. 
128 Tarman, Upaya Pemberdayaan Anak Di Panti Asuhan Kuncup Harapan Kota Bandung Melalui Pelatihan Teknologi Informasi

\section{DAFTAR PUSTAKA}

Anwas, O. M. (2014). Pemberdayaan Masyarakat di Era Globalisasi. Bandung: Alfabeta.

Bogdan, \& Taylor. (1993). Kualitatif Dasar-dasar Penelitian. Surabaya: Usaha Nasional.

Hayati \& Suparjan. (2017). Kemitraan sebagai strategi pemberdayaan masyaakat dalam program CSR batik Cap Pewarna Alamai di PT. Semen gresik Pabrik Tuban. Sosiologi USK Volume : 11 Nomor 1, 43-50.

Hayati, B. N., \& Suparjan. (2017). Kemitraan Sebagai Strategi Pemberdayaan Masyarakat Dalam Program CSR Batik Cap Pewarna Alami Di Pt. Semen Gresik Pabrik Tuban. Jurnal Sosiologi USK, 46.

Husaini, M. (2014). PEMANFAATAN TEKNOLOGI INFORMASI DALAM BIDANG PENDIDIKAN (E-education). JURNAL MIKROTIK, 1-5.

Noe, G. H., \& Wright. (2003). Pelatihan dan Pengembangan Manusia. Jakarta: Rineka Cipta.

Prasojo, L. D., \& Riyanto. (2014). Teknologi Informasi Pendidikan. Yogyakarta : Grava Media.

Prayitno, B. (2018, November Senin). Reformasi Birokrasi dan Revolusi Industri 4.0. Diambil kembali dari LAN RI: http://lan.go.id/id/berita-lan/reformasi-birokrasi-dan-revolusiindustri-4-0

Rosenberg, J. M. (2001). E-Learning : Strategies For Delivering Knowledge In The Digital Age. New York: McGraw-Hill Companies.

Setiawan, A. B. (2017). Kebijakan Teknologi Informasi dan KomunikasiUntukMendorong PembentukanModel BisnisMasa Depan. Jurnal Pekommas, 193-204.

Sugiono. (2017). Metode Penelitian Kuantitatif, Kualitatif dan R\&D. Bandung: Alfabeta. 